\title{
Well-water maintenance
}

W henever a patient mentions that household members are experiencing a bout of "stomach flu," the physician, in addition to considering testing stool samples, should enquire about the source of household drinking water. ${ }^{1}$ About one-third of Canadians live in houses - and many have cottages - that are serviced by private wells and septic tanks. Common pathogens transmitted in water from wells include Campylobacter, Escherichia and Cryptosporidium. Wells can also be contaminated by a wide variety of minerals and organic compounds, many of which may affect health.

In most jurisdictions, water from private wells is not protected by drinking-water regulations. Just as the onus is on the owner to maintain a car or replace the battery of a smoke detector, the owner of a private well must regularly test the water quality. In most circumstances, testing is recommended but not mandatory, although many property ownership transfers now involve drinking-water testing, and lending institutions are more frequently placing water-quality conditions on financing.

Private wells tap into groundwater. Most groundwater comes from rain and melting snow soaking into the ground. Water fills the spaces between rocks and soil, making an aquifer. The recharge

Table 1: Minimum distances between wells and possible sources of contamination

\begin{tabular}{ll}
$\begin{array}{l}\text { Minimum } \\
\text { distance }\end{array}$ & \multicolumn{1}{c}{ Possible source of contamination } \\
\hline $15 \mathrm{~m}$ & $\begin{array}{l}\text { Septic tank } \\
\text { Livestock yards } \\
(50 \mathrm{ft})\end{array}$ \\
& $\begin{array}{l}\text { Silos } \\
\text { Septic leach fields }\end{array}$ \\
$30 \mathrm{~m}$ & $\begin{array}{l}\text { Petroleum tanks } \\
(100 \mathrm{ft})\end{array}$ \\
& $\begin{array}{l}\text { Liquid-tight manure storage } \\
\text { Pesticide and fertilizer storage and }\end{array}$ \\
$76 \mathrm{~m}$ & handling places \\
$(250 \mathrm{ft})$ & Manure stacks \\
\hline
\end{tabular}

\section{Box 1: Contaminants in well water}

Bacteria Campylobacter, Escherichia coli, Salmonella, Shigella

Viruses Enterovirus, hepatitis, norovirus, rotavirus

Protozoa Cryptosporidium, Giardia

Chemicals Atrazine, arsenic, copper, lead, mercury, nitrate, radium, volatile organic compounds

Source: US Centers for Disease Control and Prevention, Division of Parasitic Diseases, Drinking Water (www.cdc.gov/ncidod/dpd/healthywater/privatewell.htm).

\section{Box 2: Six steps to safe well water}

1. Identify potential problem sources

2. Talk with local experts

3. Have your water tested periodically

4. Have the test results interpreted and explained clearly

5. Set a regular maintenance schedule for your well, do the scheduled maintenance and keep accurate, up-to-date records

6. Remedy any problems

Source: US Environmental Protection Agency's booklet Drinking Water from Household Wells (available: www.epa.gov/safewater/privatewells/booklet/).

area is the land area where water soaks through the earth; the water table is the line below which the ground is saturated with water. The water table will fall during dry seasons. Wells must be dug deep enough to remain in the saturated zone. In general, the deeper the well, the better the groundwater. The amount of new water flowing into the area affects groundwater quality, as do local land use activities. Minimum separation distances are recommended to keep the well safe from possible sources of contamination (Table 1).

Possible contaminants (Box 1) and the frequency of testing are largely related to potential or expected problems. It is generally recommended that well water be tested for bacteria 3 times a year and for metals and minerals once every 2 years. Good times to test are during spring run-off, after a heavy rain, after work has been done on the well, after changes in nearby land use or in the colour or smell of the water. Testing should also be done to protect household members who are pregnant. Land uses and local exposures that may alter water quality include landfill activity, road salting, installation or repair of septic tank systems, exposure to mine tailings and road construction. Wells may also be vulnerable to contamination from gasoline or solvents (because of buried storage tanks), pesticides, or oil or diesel fuel (accidental spills).

Prevention: Box 2 shows 6 basic steps for maintaining safe drinking water. Resources to assist with these steps are available through provincial ministries, local public health units and rural organizations (e.g., the Ontario Federation of Agriculture's rural water quality testing program [www.ofa.on.ca/water/ index.html]).

\section{Erica Weir}

CMAF

\section{Reference}

1. Marshall L, Weir E, Abelsohn A, Sanborn M. Identifying and managing adverse environmental health effects: 1. Taking an exposure history. CMA7 2002;166(8):1049-55. 